\title{
Advances in structural modifications of celastrol
}

\author{
Xiao-hua Cai,* Jun Jin, and Meng Huiyuan He \\ National School of Medicine, Guizhou Minzhu University, Guiyang 550 025, P. R. China \\ E-mail:caixh1111@,163.com
}

DOI: http://dx.doi.org/10.3998/ark.5550190.p009.540

\begin{abstract}
Celastrol, a quinone methide triterpenoid from the Chinese medicinal root bark of Tripterygium wilfordii, possesses beneficial therapeutic properties and affects numerous cellular pathways. Recently, structure and activity relation studies based on celastrol semi-synthetic derivatives have contributed greatly to our understanding of its mechanism of action and cellular targets. These modifications have resulted in better activity and improvement of the pharmacokinetic properties of celastrol. This review will mainly cover advances in the structural modifications of celastrol at the C-20 carboxylic acid functionality, alterations of the A ring, and modifications at C-6.
\end{abstract}

Keywords: Celastrol, triterpenoids, antitumor activity

\section{Contents}

1. Introduction

2. Modification of the C-20 Carboxylic Acid Group Functionality

3. Alteration of the A-ring and Modification at C-6

4. Summary and Outlook

5. Acknowledgements

6. References

\section{Introduction}

Over the past few decades the high activity of extracts from the medicinal herb Tripterygium wilfordii have attracted intensive attention. Celastrol (1), a quinone methide triterpenoid extracted from the root bark of the traditional Chinese medicine "Thunder of God", has been used traditionally for the treatment of various diseases such as inflammation, joint pain, edema, 
chills, and rheumatoid arthritis. ${ }^{1-6}$ Celastrol shows a great variety of biological effects such as anti-oxidant, ${ }^{7,8}$ anti-tumor, ${ }^{9-12}$ anti-obesity, ${ }^{13,14}$ cardiac protection, ${ }^{15,16}$ anti-inflammatory ${ }^{17-19}$ and antiangiogenic $^{20,21}$ activities, in both in vitro and in vivo models. It exhibits astonishing clinical potential as a therapeutic and chemopreventive agent toward various cancers. Celastrol has also been reported to inhibit growth, ${ }^{22,23}$ induce apoptosis, ${ }^{24-27}$ and suppress invasion and metastasis $^{28-30}$ of tumor cells. It is extremely effective towards many molecular targets, but there are some inherent deficiencies including high toxicity, poor stability and water solubility which impede its further application. ${ }^{31}$

The screening and assignment of active new derivatives from synthetic or semi-synthetic strategies has attracted intense interest from medicinal scientists. This review provides a summary of the recent advances in celastrol structural modifications of functionality of the C-20 carboxylic acid, alteration of the A ring at C-2, and modification of the B ring at C- 6 .

\section{Modification of the C-20 Carboxylic Acid Group Functionality}

In order to improve solubility, reduce toxicity, and develop new activities of celastrol analogues, simple modifications strategies are still the esterification or amidification of the 20-carboxylic acid group, ${ }^{32}$ for example, the $N$-propylamide (2) and cetyl ester (3), which showed antiproliferation activity similar to or better than that of celastrol in various cancer cell line assays (Scheme 1). ${ }^{33,34}$

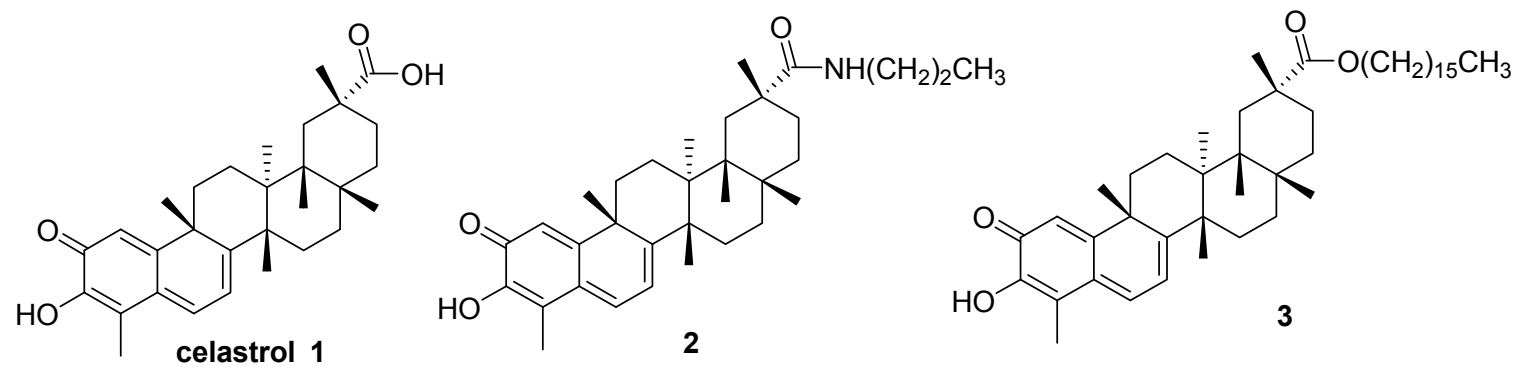

\section{Scheme 1}

In 2010, $\mathrm{Xu}$ and coworkers prepareded a series of celastrol analogues (4-16) and investigated their neuroprotective effect against t-BHP-induced cell damage in neuronal PC12 cells (Scheme 2). ${ }^{35}$ Cells treated with celastrol and compound 15 were subjected to Western blot analysis to check Hsp70 protein expression. Celastrol enormously increased the Hsp70 expression at 0.4 and $1.6 \mu \mathrm{M}$. Compound 15 improved Hsp70 expression at a concentration as low as $0.1 \mu \mathrm{M}$, but its neuroprotective effect was not evident until its concentration reached 0.4 $\mu \mathrm{M}$. Compared with celastrol, $\mathbf{1 5}$ is more effective in protecting cells from t-BHP-induced cell damage and against t-BHP-induced cytotoxicity. Compound 15 up-regulated Hsp70 protein 
expression dose-dependently and probably helped to strengthen the cellular capability to resist oxidative stress, and eventually promote cell survival. These results suggest that $\mathbf{1 5}$ may be used as a potential candidate for intervention in neurodegenerative diseases.

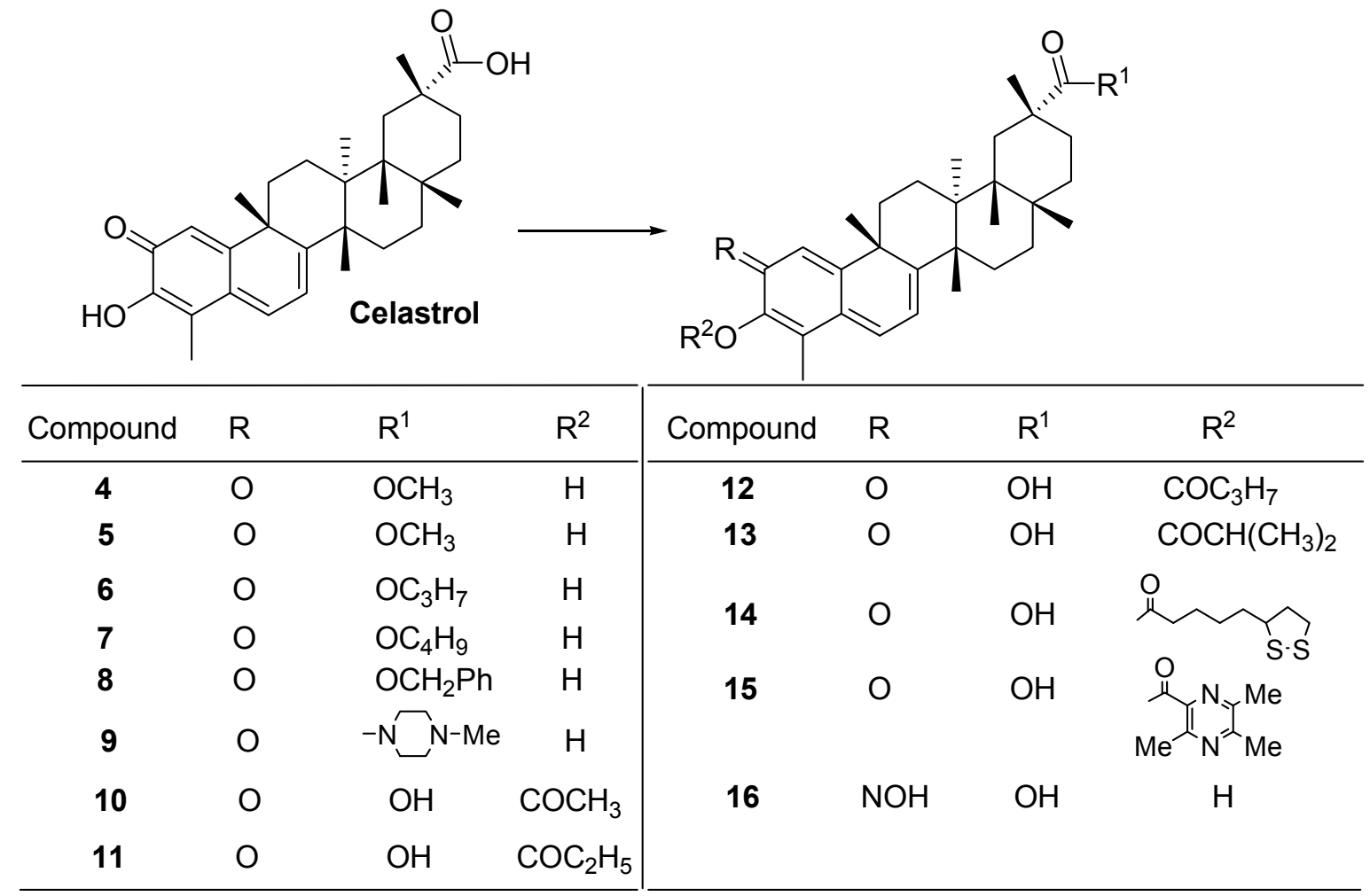

\section{Scheme 2}

To improve the aqueous solubility of celastrol, in 2012 San et al. designed and synthesized a series of celastrol derivatives of amino carbamic acid ester at C-3 of the A ring and esterification of the 20-carboxylic acid (Scheme 3). ${ }^{36}$ Although the aqueous solubility of derivatives was significantly improved, these compounds were less active than celastrol in inhibiting the proliferation activity of Bel and A-549 tumor cells.

Recently, Liu and coworkers designed and prepared a series of celastrol derivatives (17-26) as potential telomerase inhibitors (Scheme 4). ${ }^{37}$ All these compounds, including the positive control 5-fluorouracil and doxorubicin (AMD), were evaluated for their anticancer activities toward SGC-7901 (human gastric cancer cells), SMMC-7721 (human hepatoma cells), MGC803 (human gastric cancer cells) and HepG-2 (human hepatoma cells) cell lines in in vitro bioassays. Celastrol and its derivatives demonstrated remarkably potent anticancer activities with SGC-7901, SMMC-7721, MGC-803 and HepG-2 cell lines. For example, the higher activities of compounds 20 and 21 displayed excellent action against cell lines SGC-7901( $\mathrm{IC}_{50}$ 0.14-0.18 $\mu \mathrm{M}$,

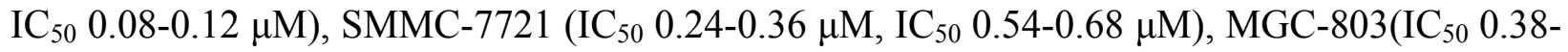
$\left.0.40 \mu \mathrm{M}, \mathrm{IC}_{50} 1.14-1.30 \mu \mathrm{M}\right)$ and HepG2 $\left(\mathrm{IC}_{50} 0.50-0.72 \mu \mathrm{M}, \mathrm{IC}_{50} 0.21-0.35 \mu \mathrm{M}\right)$. The $\mathrm{IC}_{50}$ of 
celastrol against SGC-7901, SMMC-7721, MGC-803 and HepG2 cell lines were 0.08-0.22 $\mu \mathrm{M}$, 0.40-0.76 $\mu \mathrm{M}, 1.30-1.80 \mu \mathrm{M}$ and 2.80-5.22 $\mu \mathrm{M}$, respectively.

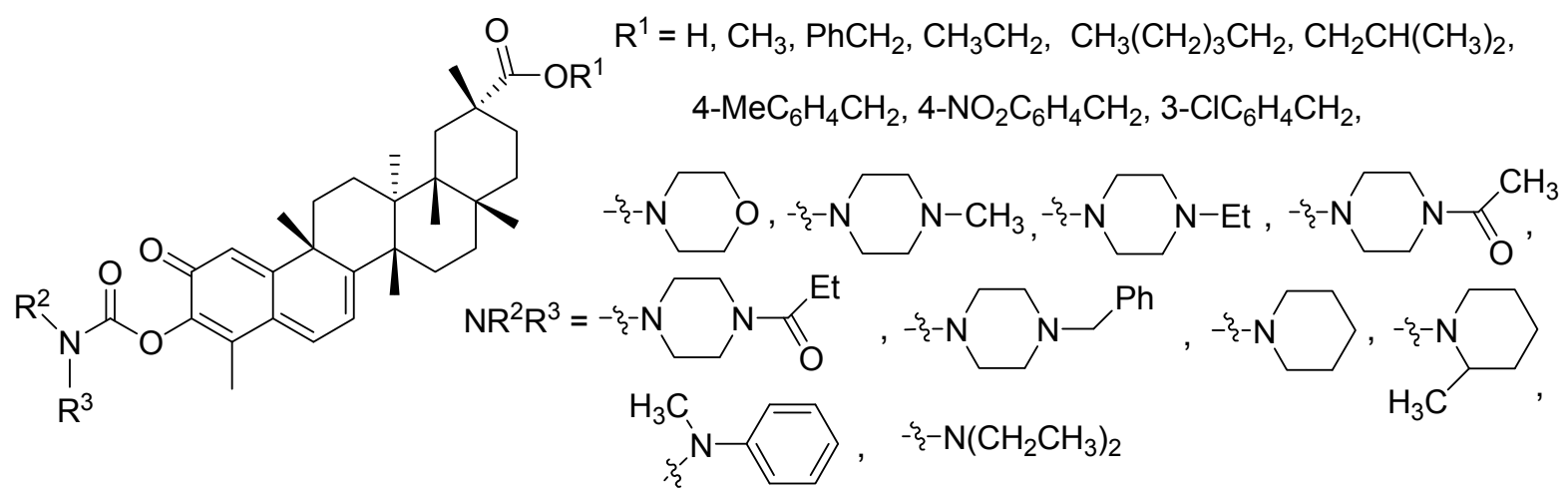

\section{Scheme 3}

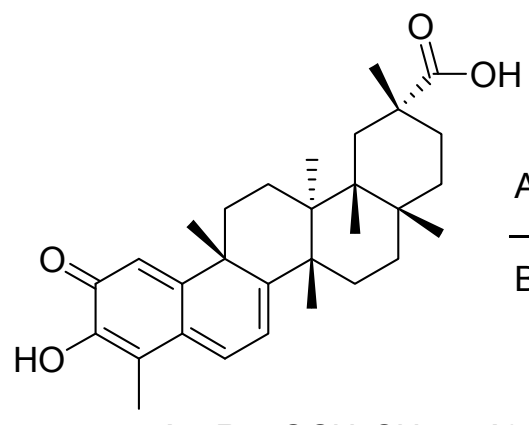

17: $\mathrm{R}=\mathrm{OCH}_{2} \mathrm{CH}_{3}$;

A: $\mathrm{NaHCO}_{3}, \mathrm{DMF}$, iodoethane, rt

B: $\mathrm{EDC} \cdot \mathrm{HCl}, \mathrm{HOBt}, \mathrm{TEA}, \mathrm{CH}_{2} \mathrm{Cl}_{2}$.<smiles>[R]C(=O)[C@]1(C)CC[C@]2(C)CC[C@]3(C)C(=CC=C4C(=CC(=O)C(O)=C4C)C3(C)C)[C@]21C</smiles>

18: $\mathrm{R}=\mathrm{NHCH}_{3} ; \quad$ 19: $\mathrm{R}=\mathrm{N}\left(\mathrm{CH}_{3}\right)_{2} ;$

20: $\mathrm{R}=\mathrm{NHCH}_{2} \mathrm{CH}_{2} \mathrm{OH}$

21: $\mathrm{R}=\mathrm{NHCH}\left(\mathrm{CH}_{3}\right) \mathrm{CH}_{2} \mathrm{OH}$;

22: $\mathrm{R}=\mathrm{NH}\left(\mathrm{CH}_{2}\right)_{3} \mathrm{CH}_{3}$;

23: $\mathrm{R}=-\xi_{2}-\mathrm{N} \mathrm{O}$;

24: $\mathrm{R}=-\xi-\mathrm{N}$

25: $\mathrm{R}=-\xi_{-}-\mathrm{N}-\mathrm{OH}$;

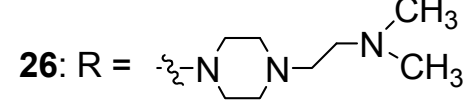

\section{Scheme 4}

The results of telomerase assay showed a direct correlation between telomerase inhibition and anti-proliferative inhibition of SMMC-7721 cells. In particular, compounds $\mathbf{2 0}$ and 21 with hydrophilic moieties exhibited high anti-proliferative activities with $\mathrm{IC}_{50}$ values at 0.11 and 0.34 $\mu \mathrm{M}$. A molecular docking study indicated that the highly active compound 20 interlinked nicely with telomerase hTERT via two hydrogen bonds and intermolecular interactions. A preliminary mechanism of antitumor action demonstrated that compound $\mathbf{2 0}$ could induce significant SMMC-7721 cell apoptosis. These results may provide an effective approach for the development of novel telomerase inhibitors based on celastrol. 
Celastrol from the natural source possesses numerous beneficial therapeutic properties and influences diverse cellular pathways. In order to understand the mechanism of action and cellular target(s) of celastrol, Morimoto and coworkers designed and synthesized a family of celastrol derivatives $\mathbf{2 7}$ and $\mathbf{2 8}$ for the identification of protein targets and investigated them as inducers toward heat shock response (Scheme 5). ${ }^{38}$ In the celastrol structure, conversion of the carboxylic acid functionality into amides or long-chain analogues leads to improvement in its potency and yields bioactive compounds that induce the heat shock response (HSR) and antioxidant response, and inhibit Hsp90 activity. The biotinylated conjugates of celastrol 27 and 28 were used as affinity reagents in extracts of human Panc-1 cells to identify Annexin II, eEF1A, and $\beta$-tubulin. The plausible results confirmed a previous suggestion that $\beta$-tubulin is another potential target of celastrol and celastrol targets Hsp90 indirectly by invoking a redox imbalance.
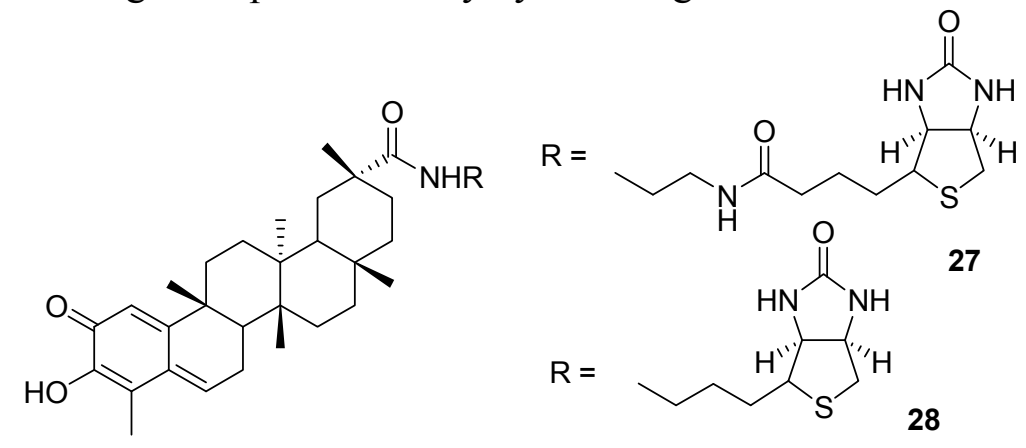

\section{Scheme 5}

\section{Alteration of the A ring and modification at C6}

In 2014, Pan and coworkers synthesized a series of new C-6-modified celastrol derivatives and evaluated them for their cytotoxic activity toward seven human cancer cell lines (BGC-823, H4, Bel7402, H522, Colo 205, HepG2 and MDA-MB-468) in vitro (Scheme 6). ${ }^{31}$ Most of the compounds exhibited higher potent inhibition against $\mathrm{BGC} 823\left(\mathrm{IC}_{50}=0.42-0.77 \mu \mathrm{M}\right), \mathrm{H} 4\left(\mathrm{IC}_{50}\right.$ $=0.35-1.37 \mu \mathrm{M})$, and Bel7402 $\left(\mathrm{IC}_{50}=0.45-1.55 \mu \mathrm{M}\right)$ than that of celastrol $\left(\mathrm{IC}_{50}=3.73 \mu \mathrm{M}, \mathrm{IC}_{50}\right.$ $=2.09 \mu \mathrm{M}$ and $\left.\mathrm{IC}_{50}=1.55 \mu \mathrm{M}\right)$. It was clear that the $\mathrm{C}-6$ functionalized celastrol derivatives possessed increased cytotoxicity potency in vitro against the human cancer cell BGC823, H4, Bel7401. In particular, 2,3-acetylation was more effective than propionylation, but the C(6)carbonated derivatives dramatically dropped in cytotoxicity potency. The compound 29-A displayed excellent inhibition of tumor growth in vivo antitumor assay on nude mice bearing Colo 205 xenografts with a $0.06 \mu \mathrm{M} \mathrm{IC}_{50}$ value. The results indicate that $\mathrm{C}-6$ functionalized celastrol derivatives may be regarded as potential drug candidates for treating cancer. 


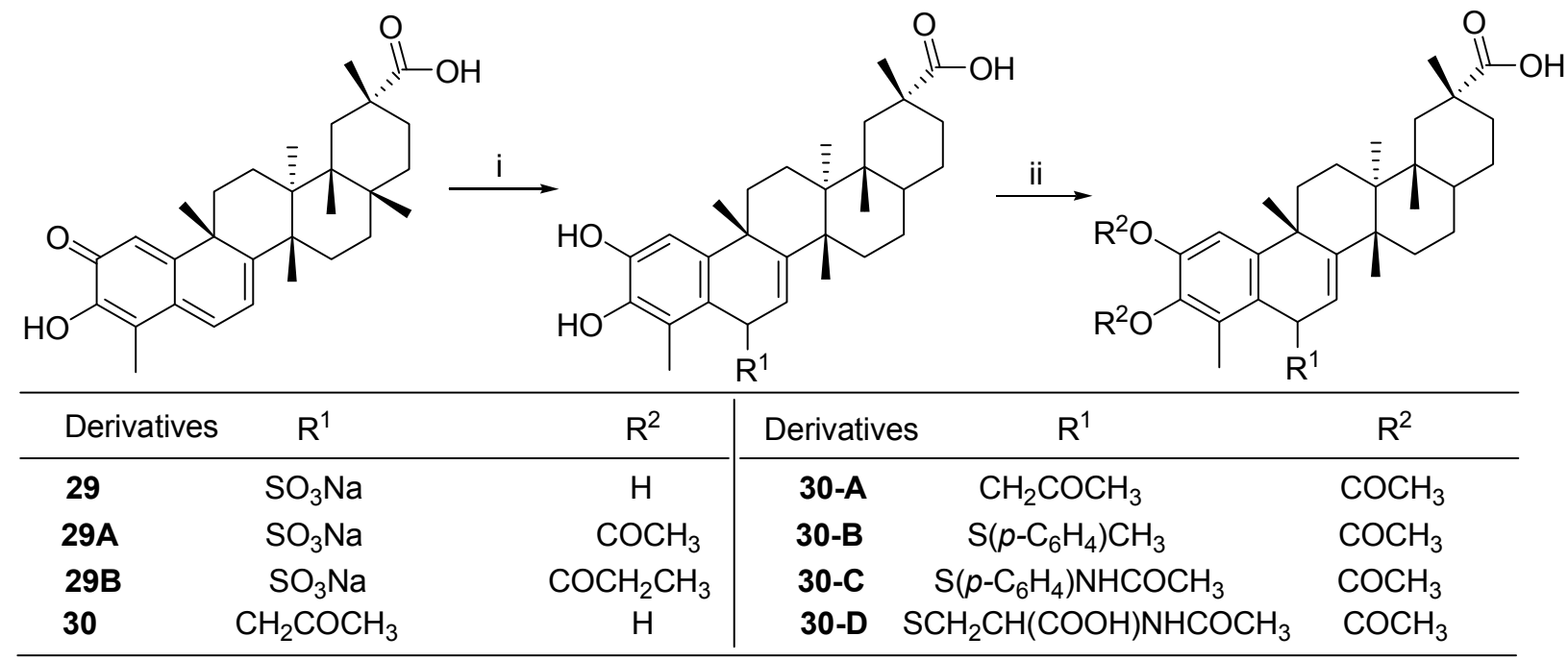

Reagents and conditions: (i) For 29: $\mathrm{NaHSO}_{3}, \mathrm{MeOH}, \mathrm{rt}, 1.5 \mathrm{~h}, \mathrm{~N}_{2}$; For 30-A: acetone, $1 \mathrm{~N} \mathrm{HCl}$ (cat.), rt, $\mathrm{N}_{2}$; For 30-B D: RSH, $\mathrm{MeOH}, \mathrm{rt}, \mathrm{N}_{2}$; (ii) $\mathrm{Ac}{ }_{2} \mathrm{O}$, Py, rt, $\mathrm{N}_{2}$; or $\left(\mathrm{CH}_{3} \mathrm{CH}_{2} \mathrm{CO}\right)_{2} \mathrm{O}, \mathrm{Py}, \mathrm{rt}, \mathrm{N}_{2}$.

\section{Scheme 6}

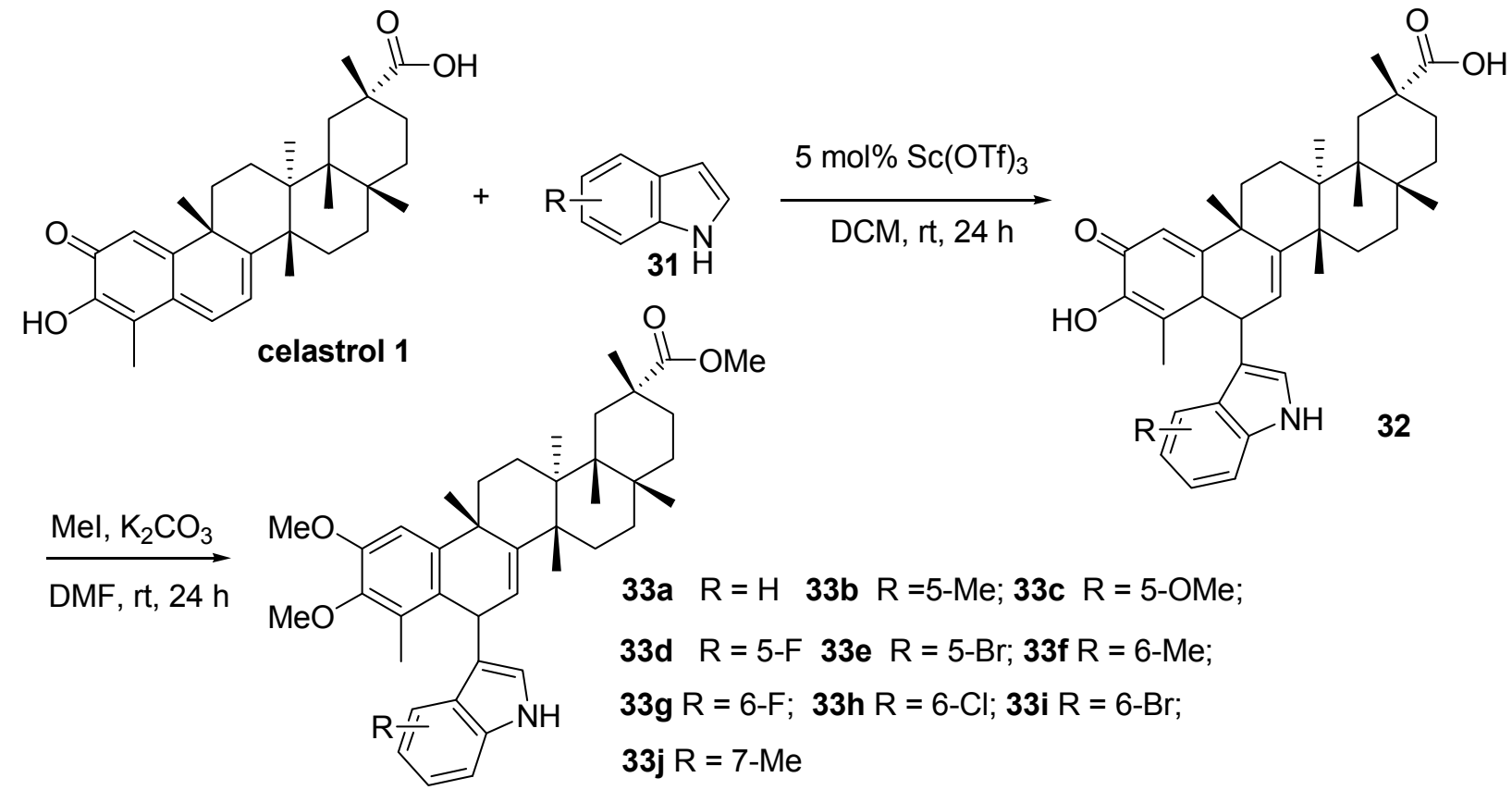

\section{Scheme 7}

In a later work, Pan and coworkers have reported a series of C-6-indole-substituted celastrol derivatives and evaluated their cytotoxic activity against human hepatocellular carcinoma Bel7402 and human glioblastoma cell line H4 (Scheme 7). ${ }^{39}$ The active compounds 
exhibited inhibition activities against $\mathrm{Bel} 7402\left(\mathrm{IC}_{50}=0.01-23.91 \mu \mathrm{M}\right)$ and $\mathrm{H} 4\left(\mathrm{IC}_{50}=2.03-\right.$ $14.56 \mu \mathrm{M}$ ), and the $\mathrm{IC}_{50}$ of celastrol as positive control against Bel7402 and $\mathrm{H} 4$ were $2.09 \mu \mathrm{M}$, $1.55 \mu \mathrm{M}$, respectively. The results from their structure-activity relationships indicated that the analogues 33f and 33h showed significant antiproliferative activities against Bel7402 cancer cells in vitro $\left(\mathrm{IC}_{50} 0.02 \mu \mathrm{M}\right.$ and $0.01 \mu \mathrm{M}$, respectively). Celastrol derivatives at C-6 position bearing a $\mathrm{C}-\mathrm{C}$ bond still displayed potent in vitro anticancer activities. In fact, the addtion of a $\mathrm{C}-\mathrm{C}$ bond at C-6 inevitably influences the Michael acceptor action and formation of a protein complex. $^{42-42}$ At the same time, the study strongly suggested that the Michael-acceptor action of celastrol is not necessary for its antitumor activity.

\section{Summary and Outlook}

Celastrol, as a representative of the natural quinone methide triterpenoids, displays wide antiinflammatory and anticancer activity and produces multiple biological effects at the molecular level. In particular, it has excellent prospects as an anti-cancer therapeutic drug in view of its perceived beneficial effects on a variety of cancers in vitro and in vivo. At present, modifications of celastrol have chiefly been focused on the C-20 carboxylic acid functionality, and alteration at the $\mathrm{A}$ ring and $\mathrm{C}-6$-modification at the $\mathrm{B}$ ring. Some authors have stated that the quinone methide moiety is required for its antitumor activity; ${ }^{32,38}$ however, while the $\mathrm{A}$ ring is transformed into a benzene ring with an alkoxy group, the corresponding derivatives still exhibit significant activities against certain tumor cell such as, BGC823, H4 and Bel7402. Some more recent studies have indicated that the $\mathrm{C}(6)$-position of celastrol was suitable for modification and have shown that the Michael acceptor property is not necessary for its anti-tumor activity. ${ }^{31,39}$ Therefore, the modifications of celastrol should focus on developing new biological activities, improving its pharmacokinetic properties, and exploring novel modifications, strategies and location points. With better understanding of the mechanism of action of celastrol, we believe that more and better celastrol derivatives will be brought about in the future.

\section{Acknowledgements}

Financial support was provided by the National Natural Science Foundation of China (21562016), the Natural Science Foundation of the Guizhou Science and Technology Department (JZ [2014]2010) and The Science and Technology Planning Project of Guiyang City $[(2012204) 23]$. 


\section{References}

1. Gunatilaka, A. A. Triterpenoid quinonemethides and related compounds (celastroloids), Springer, Wien, New York. 1996, Vol. 67, pp. 1-123.

2. Allison, A. C.; Cacabelos, R.; Lombardi, V. R.; Alvarez, X. A.; Vigo, C. Prog. Neuropsychopharmacol. Biol. Psychiatry 2001, 25, 1341-1357. http://dx.doi.org/10.1016/S0278-5846(01)00192-0

3. Morita T. Am. J. Hypertens. 2010, 23, 821.

4. Antero, S.; Marko, L.; Tuomas, P.; Kai, K. Biochem. and Biophys. Res. Commun. 2010, 394, 439-442.

5. Cascão, R.; Vidal, B.; Raquel, H.; Neves-Costa, A.; Figueiredo, N.; Gupta, V.; Fonseca, J. E.; Moita, L. F. Autoimmun. Rev. 2012, 11, 856-862. http://dx.doi.org/10.1016/j.autrev.2012.02.022

6. Nanjundaiah, S. M.; Venkatesha, S. H.;Yu, H.; Tong, L.; Stains, J. P.; Moudgil, K. D. J. Biol. Chem. 2012, 287, 22216-22226. http://dx.doi.org/10.1074/jbc.M112.356816

7. Allison, A. C.; Cacabelos, R.; Lombardi, V. R. M.; Alvarez, X. A.; Vigo, C. CNS Drug Rev. 2000, 6, 45-62. http://dx.doi.org/10.1111/j.1527-3458.2000.tb00137.x

8. Seo, H. R.; Seo, W. D.; Pyun. B.-J.; Lee, B. W.; Jin, Y. B.; Park, K. H.; Seo, E.-K.; Lee, Y.-J.; Lee, Y.-S. Chem-Bio. Interact. 2011, 193, 34-42. http://dx.doi.org/10.1016/j.cbi.2011.04.009

9. Zhu, H.; Ding, W.-J.; Wu, R.; Weng, Q.-J.; Lou, J.-S.; Jin, R.-J.; Lu, W.; Yang, B.; He, Q.-J. Cancer Invest. 2010, 28, 23-32. http://dx.doi.org/10.3109/07357900903095664

10. Jo, H.; Loison, F.; Hattori, H.; Silberstein, L. E.; Yu, H. T.; Luo, H. R. PLoS ONE 2010, 5, 103-118.

11. Kannaiyan, R.; Shanmugam, M. K.; Sethi, G. Cancer Lett. 2011, 303, 9-20. http://dx.doi.org/10.1016/j.canlet.2010.10.025

12. Shrivastava, S.; Jeengar, M. K.; Reddy, V. S.; Reddy, G. B.; Naidu, V. G. M. Exp. Mol. Pathol. 2015, 98, 313-327. http://dx.doi.org/10.1016/j.yexmp.2015.03.031

13. Liu, J. L.; Lee, J.; Hernandez, M A.; Mazitschek, R.; Ozcan, U. Cell. 2015, 161, 999-1011. http://dx.doi.org/10.1016/j.cell.2015.05.011

14. Wang, C. Y; Shi, C. F.; Yang, X. P.; Yang, M.; Sun, H. L.; Wang. C. H. Eur. J. Pharmacol. 2014, 744, 52-5 http://dx.doi.org/10.1016/j.ejphar.2014.09.043

15. Der Sarkissian, S.; Cailhier J.; Borie M.; Mansour S.; Hamet P.; Stevens, L.; Noiseux, N. Can. J. Cardiol. 2013, 29, S331. 
16. Der Sarkissian, S.; Cailhier J.; Borie M.; Stevens, L.; Gaboury, L.; Mansour, S.; Noiseux, N. Can. J. Cardiol. 2014, 30, S82-S83.

17. Salminen, A.; Lehtonen, M.; Paimela, T.; Kaarniranta, K. Biochem. Biophys. Res. Commun. 2010, 394, 439-442.

http://dx.doi.org/10.1016/j.bbrc.2010.03.050

18. Lourenço, A. M.; Ferreira, L. M.; Branco, P. S. Curr. Pharm. Des. 2012, 18, 3979-4046.

19. Yang, L. H.; Li, Y. T.; Ren, J.; Zhu, C. G.; Fu, J.; Lin, D. H.; Qiu, Y. Int. J. Mol. Sci. 2014, $15,13637-13648$.

http://dx.doi.org/10.3390/ijms150813637

20. Zhou Y.-X.; Huang, Y.-L. Chin. Med. J. 2009, 122, 1666-1673.

21. Hu, Y. S.; Qi, Y. P.; Liu, H. Fan, G. R.; Chai, Y. F. Biochem. Biophys. Res. Commun. 2012, 396, 467-472.

22. Jang, S. Y.; Jang, S.-W.; Ko, J. Cancer Lett. 2011, 300, 57-65.

http://dx.doi.org/10.1016/j.canlet.2010.09.006

23. Kannaiyan, R.; Manu, K. A.; Chen, L. X.; Li, F.; Rajendran, P.; Subramaniam, A.; Lam, P.; Kumar, A. P.; Sethi, G. Apoptosis 2011, 16, 1028-1041.

http://dx.doi.org/10.1007/s10495-011-0629-6

24. Li, P.-P.; He, W.; Yuan, P.-F.; Song, S.-S.; Lu, J.-T.; Wei, W. Am. J. Chin. Med. 2015, $43,137-148$.

http://dx.doi.org/10.1142/S0192415X15500093

25. Lu, W. Z.; Jia, G. F.; Meng, X. Y.; Zhao, C.; Zhang, L.; Ren, Y. M.; Pan, H. X.; Ni, Y. Life Sci. 2012, 91, 279-283.

http://dx.doi.org/10.1016/j.1fs.2012.07.032

26. Mi, C. L.; Shi, H.; Ma, J; Han, L. Z; Lee, J. J.; Jin, X. J. Oncol. Rep. 2014, 32, 2527-2532.

27. Chow, A. M.; Tang, D. W. F.; Hanif, A.; Brown, I. R. Cell Stress Chaperones 2013, 18 , $155-160$.

http://dx.doi.org/10.1007/s12192-012-0364-0

28. Ni, H.; Zhao, W.; Kong, X.; Li, H.; Yang, J. O. Acta Haematol. 2014, 131, 102-111. http://dx.doi.org/10.1159/000354770

29. Yadav, V. R.; Sung, B.; Prasad, S.; Kannappan, R.; Cho, S.-G.; Liu, M. Y.; Chaturvedi, M. M.; Aggarwal, B. B. J. Mol. Med. 2010, 88, 1243-1253.

http://dx.doi.org/10.1007/s00109-010-0669-3

30. Kim, Y.; Kang, H.; Jang, S.-W.; Ko, J. Cellular Physiol. Biochem. 2011, 28, 175-184. http://dx.doi.org/10.1159/000331729

31. Tang, K. Y.; Huang, Q. Q.; Zeng, J. F.; Wu, G. M.; Huang, J. W.; Pan, J. F.; Lu, W. Molecules 2014, 19, 10177-10188. http://dx.doi.org/10.3390/molecules190710177

32. Salvador, J. A. R.; Santos, R. C.; Figueiredo, S. A. C.; Jing, Y. Mini-Rev. Org. Chem. 2014, 11, 400-407. http://dx.doi.org/10.2174/1570193X1103140915113701 
33. Liu, K.; Guan, Y.; Zhao, F.; Shao, M.; Xu, H. CN Patent 101311 187-A. 2009.

34. Zhou, Y. CN Patent 101624 415, 2008.

35. Sun, H. L.; Xu, L. P.; Yu, P.; Jiang, J.; Zhang, G. X.; Wang, Y. Q. Bioorg. Med. Chem. Lett. 2010, 20, 3844-3847. http://dx.doi.org/10.1016/j.bmcl.2010.05.066

36. Shan, W. G.; Zhan, Z. G.; Zhang, L. W.; Wen, Y. T.; Chen, Y.; Wang, J. W.; Yu, H, N.; Hou, X. H. CN Patent 102432 663-A, 2012.

37. Tang, W.-J.; Wang, J.; Tong, X.; Shi, J.-B.; Liu, X.-H.; Li, J. Eur. J. Med. Chem. 2015, 95, 166-173.

http://dx.doi.org/10.1016/j.ejmech.2015.03.039

38. Klaić, L.; Morimoto, R. I.; Silverman, R. B. ACS Chem. Biol. 2012, 7, 928-937

39. Tang, K. Y.; Huang, J. W.; Pan, J. F.; Zhang, X.; Lu, W. RSC Adv. 2015, 5, 19620-19623. http://dx.doi.org/10.1039/C4RA15414B

40. Sreeramulu, S.; Gande, S. L.; Gobel, M. Schwalbe, H. Angew. Chem. Int. Ed. 2009, 48, 5853-5855.

http://dx.doi.org/10.1002/anie.200900929

41. Liu, Z.; Ma, L.; Zhou G.-B. Molecules 2011, 16, 5283-5297. http://dx.doi.org/10.3390/molecules16065283

42. Corson, T. W.; Crews, C. M. Cell 2007, 130, 769-774.

\section{Authors' Biographies}

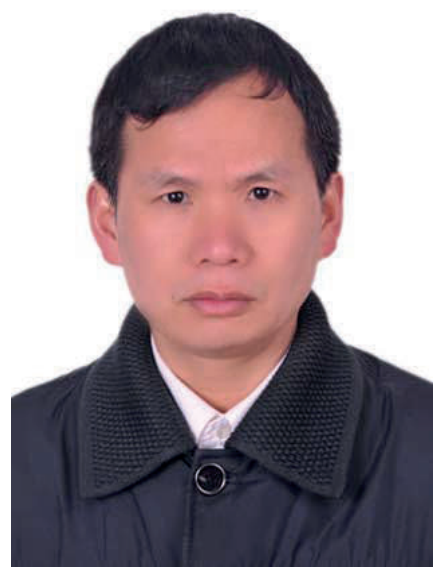

Xiao-hua Cai was born in 1966. He graduated at Shaoyang Technology University, China, in 1988. He received his M.S. in chemistry from Xi'an Modern Chemistry Research Institute in 1999, and his Ph.D. in sciences from Graduate School of the Chinese Academy of Sciences in 2005. He became a professor at National School of Medicine, Guizhou Minzu University in 2006. His current research interests cover asymmetric catalysis and organic synthesis and bioactivity of natural products. 


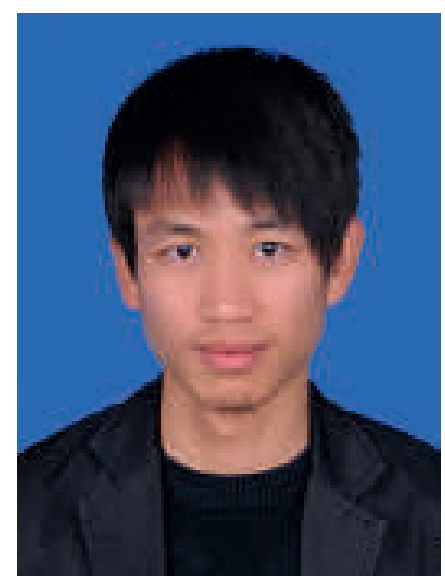

Jun Jin was born in Guizhou, China, in 1987. He received his Bachelor degree in 2013 from the Guizhou Minzu University, Guiyang. He is currently a third-year master's degree candidate at the Guizhou Minzu University, focusing on organic reactions and modifications of natural products.

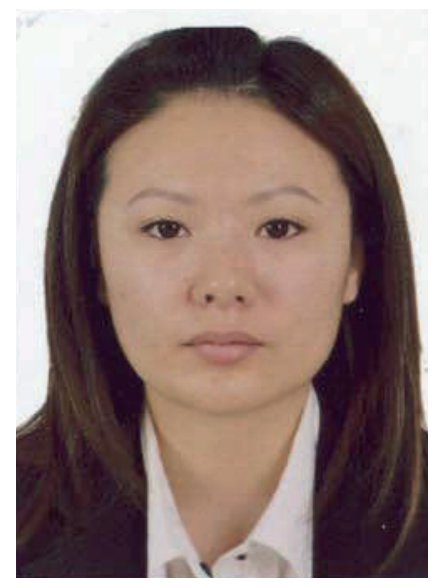

Meng Huiyuan He was born in Guizhou, China, in 1988. She received her Bachelor's degree in 2012 from Guangdong Pharmaceutical University, Guangzhou. She is currently a third-year master's degree candidate at the Guizhou Minzu University, focusing on extraction and separation of active components and modifications of natural products. 